\title{
Characterization of Aspergillus niger B-1 RNase and Its Inhibitory Effect on Pollen Germination and Pollen Tube Growth in Selected Tree Fruit
}

\author{
Levava Roiz, Uzi Ozeri, Raphael Goren, and Oded Shoseyov \\ The Kennedy Leigh Centre for Horticultural Research, The Faculty of Agriculture, The Hebrew \\ University of Jerusalem, P.O. Box 12, Rehovot 76100, Israel
}

AdDitional IndeX words. RNase B1, Citrus reticulata, peach, pollen tube growth, Prunus persica (Peach Group), tangerine

\begin{abstract}
Aspergillus niger B-1 (CMI CC 324626) extracellular RNase (RNase B1) was purified to homogeneity. It was found to contain two isoforms of 32- and 40-kDa glycoproteins, sharing a 29-kDa protein moiety. Optimal RNase activity was observed at $60^{\circ} \mathrm{C}$ and pH 3.5. In 'Almog' peach [Prunus persica (L.) Batsch (Peach Group) 'Almog'] and 'Murcott' tangerine (Citrus reticulata Blanco 'Murcott') the enzyme inhibited pollen germination and pollen tube growth in vitro as well as in vivo. In field experiments, spray application of the RNase caused a reduction in 'Fantasia' nectarine [Prunus persica (L.) Batsch (Nectarine Group) 'Fantasia'] fruit set and interfered with embryo development. The biological effect of the RNase may be of horticultural value, due to its potential to control fertilization.
\end{abstract}

In self-incompatible plants, growth of self-pollen is arrested in the stigma or style, before fertilization occurs. Self-incompatibility is often controlled by a single multiallellic $S$-gene (de Nettancourt, 1977). A common outbreeding mechanism is gametophytic self-incompatibility, in which a pollen tube bearing an Sallele identical to one of the two alleles of the pistil fails to achieve fertilization (Clarke and Newbigin, 1993; Haring et al., 1990; Hinata et al., 1993; Newbigin et al., 1994; Singh and Kao, 1992). In members of Solanaceae and Rosaceae, the $S$-alleles have been found to encode stylar-specific S-glycoproteins exhibiting ribonuclease (RNase) activity, as well as the ability to inhibit the growth of self-pollen tubes (Clarke et al., 1990; Kaufmann et al., 1991; Kirch et al., 1989; McClure et al., 1989; Sassa et al., 1992). Two domains in the primary structure of these S-glycoproteins, containing one histidine residue each show strong homology to Aspergillus oryzae (Ahlburg) Cohn RNase $\mathrm{T}_{2}$, Rizopus niveus Yamazaki IFO 4810 RNase Rh (McClure et al., 1989), and A. saitoi Sakaguchi et al. RNase M (Watanabe et al., 1990).

In some plants non-S-allele-specific ribonucleases were found to be produced by the female organs. For example, RNase X has been reported to be shared by both self-incompatible Nicotiana alata Link et Otto and self-compatible N. tabacum (L.) (McClure et al., 1989). In self-incompatible Petunia inflata Fries RNase $\mathrm{X}_{2}$ shares homology with S-RNases, yet its gene is not located on the S-locus (Lee et al., 1992). The biological traits and function of these RNases were not fully determined yet. In self-compatible peach [Prunus persica (Peach Group)] and calamondin (Citrus reticulata 'Austera' $\mathrm{x}$ Fortunella sp. Swingle) the stigmatic diffusate contains RNase activity (Roiz and Shoseyov, 1995; Roiz et al., 1995). These stigmatic RNases inhibit pollen germination and tube elongation in vitro in a dose-responsive manner. Furthermore, it was shown in the above studies that bovine pancreatic RNase A and A. oryzae RNase T1, which are nonspecific, had similar inhibitory effect in peach and calamondin, respectively. In both species in vitro studies suggest that non-Sallele RNases play a role in the pollination process.

The effect of nonspecific RNase may be of horticultural value.

Received for publication 14 Jan. 1999. Accepted for publication 7 Oct. 1999. The cost of publishing this paper was defrayed in part by the payment of page charges. Under postal regulations, this paper therefore must be hereby marked advertisement solely to indicate this fact.
In many deciduous fruit trees, yields of commercial value depend upon massive thinning of the flowers and fruitlets. In stone fruits [peach, plum (Prunus domestica L.), etc.] the thinning process is currently performed manually. In Citrus L. trees, on the other hand, seedless fruits are desirable. Therefore, a further step in this research was to examine an effective RNase that can be produced in large amounts. Species of Aspergillus have been reported to produce extracellular RNases (Egami and Nakamura, 1969). Aspergillus niger is also used as a source for important materials and enzymes in the food industry, such as citric acid and pectinases (Kerns et al., 1987; Li and King, 1963; Rombout and Pilnik, 1978). In the present work we describe production, purification, and partial characterization of A. niger B-1 extracellular RNase (RNase B1) and its effect on in vitro and in vivo pollen germination and pollen tube growth.

\section{Materials and Methods}

Preparation and purification of a. niger extracellular RNasE. Aspergillus niger B1 (CMI CC 324626) was grown in liquid culture containing $1 \%(\mathrm{w} / \mathrm{v})$ wheat flour and $0.05 \%(\mathrm{w} / \mathrm{v})$ $\left(\mathrm{NH}_{4}\right)_{2} \mathrm{SO}_{4}$. The mixture was adjusted to $\mathrm{pH} 3.5$ with $\mathrm{HCl}$ and autoclaved. An inoculum of $\approx 10^{6}$ spores was suspended in 100 $\mathrm{mL}$ of medium and incubated at $30^{\circ} \mathrm{C}$ in an orbital shaker, at 200 $\mathrm{rpm}$ for $100 \mathrm{~h}$. The growth medium was passed through a $0.2-\mu \mathrm{m}$ membrane and dialyzed three times against 10 volumes of $2 \mathrm{~mm}$ sodium acetate $\mathrm{pH} 6$. Two liters of dialyzed solution were loaded onto a Fractogel EMD-TMAE 650 (м) 26/10 (Merck, Darmstadt, Germany) column, equilibrated with 20 mm sodium acetate $\mathrm{pH} 6$. Bound proteins were eluted with a $500-\mathrm{mL}$ linear gradient of 0 to $1.0 \mathrm{M} \mathrm{NaCl}$ in the same buffer, using a fast protein liquid chromatography (FPLC) system (Amersham Pharmacia Biotech, Buckinghamshire, U.K.) at a flow rate of $5 \mathrm{~mL} \cdot \mathrm{min}^{-1}$. The fractions exhibiting the highest RNase activity were pooled and dialyzed against $2 \mathrm{mM}$ sodium acetate $\mathrm{pH}$, and a 50-mL aliquot was loaded onto a Mono Q 5/5 HR (Amersham Pharmacia Biotech) column, equilibrated with $20 \mathrm{mM}$ sodium acetate $\mathrm{pH}$ 6. The elution was performed as with the EMD-TMAE column, except that only $10 \mathrm{~mL}$ of a 0 to $1.0 \mathrm{M}$ salt gradient were used, at a flow rate of $1 \mathrm{~mL} \cdot \mathrm{min}^{-1}$.

Proteins were monitored at $280 \mathrm{~nm}$ and measured according to 
Bradford (1976), using bovine serum albumin (BSA) as a standard. Different fractions were analyzed by $12.5 \%$ sodium dodecyl sulfate-polyacrylamide gel electrophoresis (SDS-PAGE; Laemmeli, 1970). An RNase activity gel was run according to Roiz and Shoseyov (1995).

The purified RNase B1 was deglycosylated enzymatically according to the procedure of Broothaerts et al. (1991). The enzyme was mixed with $0.5 \%(\mathrm{w} / \mathrm{v}) \operatorname{SDS}$ and $5 \%(\mathrm{w} / \mathrm{v}) \beta$ mercapthoethanol and heated at $100{ }^{\circ} \mathrm{C}$ for $5 \mathrm{~min}$. Once cooled, the reaction mixture was diluted 2.5 -fold with buffer containing $50 \mathrm{~mm}$ sodium phosphate $\mathrm{pH} 7.5,25 \mathrm{~mm}$ EDTA, $1 \%$ (w/v) Triton $\mathrm{X}-100$, and $0.02 \%(\mathrm{w} / \mathrm{v})$ sodium azide. Peptide-N-glycosidase F (PNGase F, Boehringer-Mannheim GmbH, Mannheim, Germany) was added to a final concentration of 20 units $/ \mathrm{mL}$ and incubated overnight at $37^{\circ} \mathrm{C}$. The sample was then mixed with sample application buffer, heated at $100{ }^{\circ} \mathrm{C}$ for $5 \mathrm{~min}$, and analyzed by $12.5 \%$ SDS-PAGE.

RNaSe ASSAYS. The optimal conditions for RNase activity were determined within a range of temperatures from 20 to $100{ }^{\circ} \mathrm{C}$ at $10^{\circ} \mathrm{C}$ intervals, and across a $\mathrm{pH}$ range from 2.5 to 7 at $0.5 \mathrm{pH}$ units intervals, using phosphate-citrate buffer (50 and $12 \mathrm{~mm}$, respectively). The RNase activity assay was modified from Brown and Ho (1986). Samples of $10 \mu \mathrm{L}$ were added each to $490 \mu \mathrm{L}$ of icecold buffer, containing $4 \mathrm{mg} \cdot \mathrm{mL}^{-1}$ yeast RNA (Sigma, St. Louis, Mo). Half of the mixture was moved immediately to another tube containing $50 \mu \mathrm{L} 0.75 \%(\mathrm{w} / \mathrm{v})$ uranyl sulfate in $25 \%(\mathrm{w} / \mathrm{v})$ perchloric acid (stop mixture), for use as a blank. The rest was incubated for $10 \mathrm{~min}$, then $50 \mu \mathrm{L}$ of stop mixture were added. Following centrifugation at $15,000 g_{\mathrm{n}}$ for $5 \mathrm{~min}$, the supernatant was diluted 20-fold with distilled water and absorbance was determined at $260 \mathrm{~nm}$. One unit of RNase activity was determined as the amount of enzyme releasing soluble nucleotides at a rate of one A $260 \mathrm{~nm} \cdot \mathrm{min}^{-1}$.

RNase B1 was visualized by an activity gel, as modified from Roiz and Shoseyov (1995). An SDS gel containing RNase B1 was renatured by washing twice for 15 min each with 20 mm sodium acetate $\mathrm{pH} 3.5$ containing $25 \%$ (v/v) isopropanol and then twice for 15 min each with buffer alone. The renatured gel was laid over a plate containing $0.1 \%$ RNA and $0.8 \%$ agarose in 20 mm sodium acetate and incubated at $37^{\circ} \mathrm{C}$ for $30 \mathrm{~min}$. The gel was then removed and the agarose plate was stained with $0.02 \%(\mathrm{w} / \mathrm{v})$ toluidine blue in water to visualize RNase activity.

Effect of RNase B1 ON POLlen tube Growth. Pollen of 'Almog' Peach germinated in vitro in liquid culture, as described by Roiz and Shoseyov (1995). Pollen grains were suspended in aliquots containing $100 \mu \mathrm{L} 15 \%(\mathrm{w} / \mathrm{v})$ sucrose, $100 \mu \mathrm{g} \cdot \mathrm{mL}^{-1}$ boric acid, $200 \mu \mathrm{g} \cdot \mathrm{mL}^{-1}$ magnesium sulfate, $200 \mu \mathrm{g} \cdot \mathrm{mL}^{-1}$ calcium nitrate and different concentrations of RNase B1. After incubation overnight at $25^{\circ} \mathrm{C}$ in a dark chamber, percent germination was recorded. Pollen tube length was examined by light microscopy with an eyepiece micrometer.

The effect of RNase B1 treatment on pollen tube growth was tested also in vivo. In peach and in tangerine (Citrus reticulata 'Murcott') intact flowers at the very beginning of anthesis, were sprayed with RNase B1 diluted in $20 \mathrm{~mm}$ citrate buffer $\mathrm{pH} 3.5$ to a concentration of $0.2 \mathrm{mg} \cdot \mathrm{mL}^{-1}$ protein, having $100 \mathrm{units} / \mathrm{mL}$ RNase activity. In each species additional flowers at the same stage, on different branches, were sprayed with buffer alone or remained nontreated as controls. After exposure to open pollination for $48 \mathrm{~h}$, the styles were fixed in 3 acetic acid : 1 ethanol (by volume) for $24 \mathrm{~h}$, washed with distilled water and imbibed overnight in $8 \mathrm{~m} \mathrm{NaOH}$. Following thorough washes in distilled water, the styles were cut longitudinally, immersed each in a drop of $0.1 \%(\mathrm{w} / \mathrm{v})$ aniline blue in $0.1 \mathrm{~m}$ potassium phosphate on a slide and carefully squashed with a cover slip. Pollen tubes were observed by epifluorescence microscopy (model BX40, equipped with WIB cube; Olympus Optical Co., Hamburg, Germany).

THE EFFECT OF RNASE B1 ON FRUIT SET. Field experiments were conducted in April 1994 using trees of 'Fantasia' nectarine [Prunus persica (Nectarine Group) 'Fantasia'] growing in Rosh Zurim, Israel. Branches 30 to $40 \mathrm{~cm}$ long, bearing $\approx 10 \%$ open flowers, were sprayed with different concentrations of RNase B1 in $20 \mathrm{~mm}$ citrate buffer $\mathrm{pH} 3.5$ and $0.025 \%$ triton-X 100 . Nontreated branches, and branches sprayed with only buffer and triton-X 100, served as controls. The branches were sprayed at 2to 3-d intervals during the blooming period (14 d). A month later, the number of fruit per branch was examined. For viability tests, seeds were cut longitudinally through the embryo and immersed in one percent 2,3,5-triphenyl tetrazoluim chloride in water for 4 $\mathrm{h}$ at $20^{\circ} \mathrm{C}$ in the dark. Red staining indicated viable tissues.

\section{Results}

Purification and Characterization of Rnase B1. Aspergillus niger grown in liquid culture produced considerable amounts of extracellular RNase. A temperature of $60^{\circ} \mathrm{C}$ and pH 3.5 were found optimal for RNase activity (Fig. 1), and were adopted as the standard conditions for RNase assays.

Purification of RNase B1 consisted of two steps (Table 1). The crude filtrate contained 1000 units $/ \mathrm{mL}$ and $0.05 \mathrm{mg} \cdot \mathrm{mL}^{-1}$ protein. The pooled fractions around the active RNase peak eluting at 0.62 $\mathrm{M} \mathrm{NaCl}$ (Fig. 2A) from an EMD-TMAE column, contained 0.1 $\mathrm{mg} \cdot \mathrm{mL}^{-1}$ protein, with an RNase activity of 40,000 units $/ \mathrm{mL}$. In the final step, the RNase was eluted from a Mono Q column at 0.5

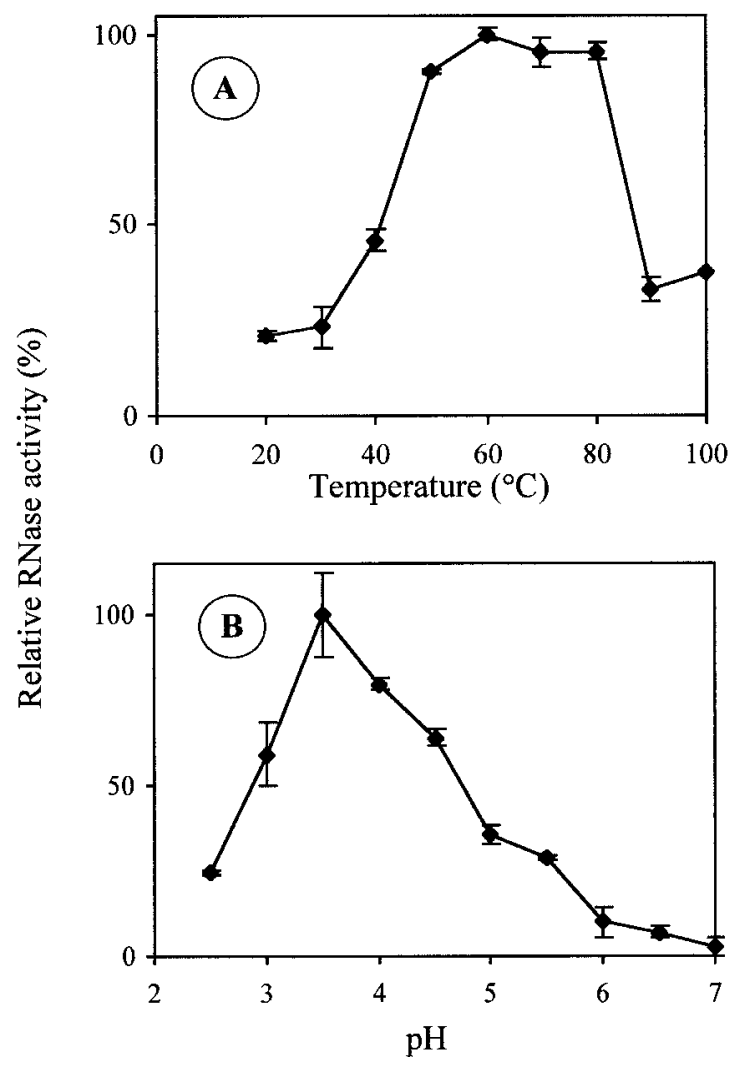

Fig. 1. Activity plots of RNase B1 as a function of (A) temperature and (B) $\mathrm{pH}$. 
Table 1. Purification of RNase B1 from growth medium filtrate of A. niger B-1. Protein concentration and RNase activity were monitored during enzyme purification.

\begin{tabular}{|c|c|c|c|c|c|}
\hline Purification step & $\begin{array}{c}\text { Total vol } \\
\text { of extract } \\
(\mathrm{mL})\end{array}$ & $\begin{array}{c}\text { Total RNase } \\
\text { activity } \\
\text { (units } \times 10^{3} \text { ) }\end{array}$ & $\begin{array}{c}\text { Protein } \\
\text { concn } \\
\left(\mathrm{mg} \cdot \mathrm{mL}^{-1}\right)\end{array}$ & $\begin{array}{c}\text { Recovery } \\
(\%)\end{array}$ & $\begin{array}{c}\text { Specific activity } \\
\text { units } \times 10^{3} / \\
\text { mg protein) }\end{array}$ \\
\hline Crude filtrate & 2000 & 2000 & 0.05 & 100 & 20 \\
\hline EMD-TMAE column & 28 & 1120 & 0.1 & 56 & 400 \\
\hline Mono-Q column & 1.2 & 652 & 1.05 & 32.6 & 517 \\
\hline
\end{tabular}

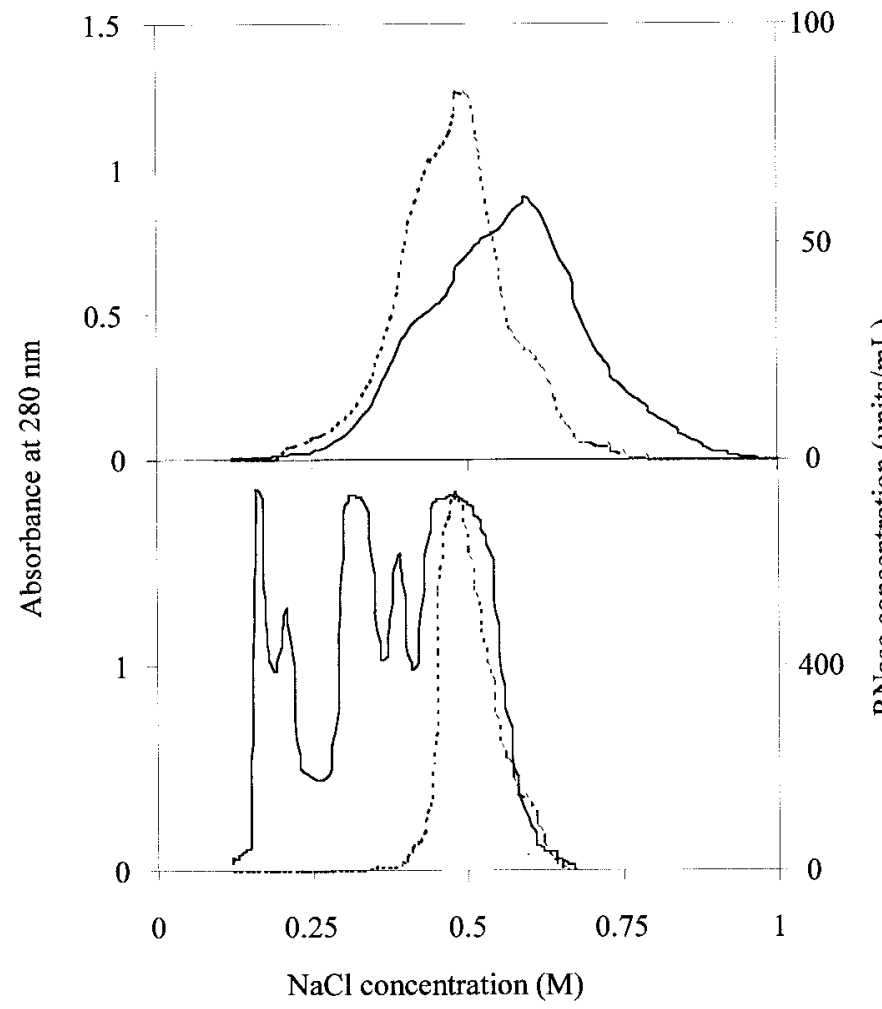

Fig. 2. Anion exchange chromatography of RNase B1. The solid line = absorbance at $280 \mathrm{~nm}$ and the dashed line = RNase activity. (A) The crude filtrate was dialyzed and loaded onto an EMD-TMAE column. Each 7-mL fraction was located in a separate tube. (B) Fractions eluted in 0.55 to $0.65 \mathrm{~m} \mathrm{NaCl}(\mathbf{A})$, showing highest RNase activity, were pooled and loaded onto a Mono-Q column. Each $0.5-\mathrm{mL}$ fraction was collected in a separate tube.

$\mathrm{M} \mathrm{NaCl}$ (Fig. 2B); the eluant had protein concentration and RNase activity of $1.05 \mathrm{mg} \cdot \mathrm{mL}^{-1}$ and 543,000 units $/ \mathrm{mL}$, respectively. Two major protein bands, of 40 and $32 \mathrm{kDa}$, were observed following SDS-PAGE of the purified RNase B1 (Fig. 3). An RNase activity gel showed active bands corresponding to the 32 and the $40 \mathrm{kDa}$ proteins. When subjected to PNGase F, a single protein band appeared at $29 \mathrm{kDa}$. RNase activity was retained after PNGase digestion (data not presented).

EFFECT OF RNASE B1 ON POLLEN TUBES AND FRUIT SET. Seventy five percent of the control peach pollen grains germinated in vitro and the pollen tubes reached $0.48 \pm 0.03 \mathrm{~mm}$ in length. Addition of RNase B1 to the growth medium reduced percentage germination and the length of the pollen tubes, in a dose responsive manner (Fig. 4) . RNase B1 had a pronounced inhibitory effect, considering that 50 units $/ \mathrm{mL}$, representing $0.1 \mathrm{mg} \cdot \mathrm{mL}^{-1}\left(2.8 \times 10^{-3} \mathrm{~mm}\right)$ protein, were found lethal, whereas BSA at a 680-fold higher concentration of $125 \mathrm{mg} \cdot \mathrm{mL}^{-1}(1.9 \mathrm{~mm})$ protein, reduced only $50 \%$ of pollen germinability and tube growth.

Control pollen tubes of peach were observed growing in vivo through the stigmatic tissue directed into the style, $48 \mathrm{~h}$ after pollination (Fig. 5A). A similar picture was observed in styles treated with buffer only. In contrast, pollen grains germinated on stigmas treated with RNase B1 produced short pollen tubes, which appeared to lack any growth orientation, and failed to penetrate the stylar tissue (Fig. 5B). In tangerine only a small portion of the stigmatic tissue, of which the diameter was 2 to 3 $\mathrm{mm}$, could be observed in the microscopic field. Therefore, only a few pollen tubes were captured in the microscopic field, as shown in Fig. 6. However, the difference between the normal growth of the control pollen tubes (Fig. 6A) and the irregular growth of the RNase-treated pollen tubes (Fig. 6B), was observed clearly.

In 'Fantasia' nectarine RNase B1 caused a reduction in fruit set (Table 2). In nontreated branches or branches sprayed with buffer containing triton X-100, fruit set was $48.3 \%$ and $36.3 \%$, respectively. It seemed that the low pH-buffer had some inhibitory effect on fruit set, however branches treated with 500 and 1000 units/mL of RNase B1 set $23.3 \%$ and $18.4 \%$ fruit, respectively, indicating a significant thinning effect of the RNase, with a dose dependent response.

In RNase B1 treated branches, many undeveloped fruitlets were observed. Viability tests showed that in nonntreated flowers or flowers spayed with buffer, most embryos cut surfaces were stained red, whereas embryos born in RNase-treated flowers, unevenly stained cut surfaces with brown necrotic tissues were found.

\section{Discussion}

An effective fermentation and purification process was developed for production of RNase B1 (Ozeri, 1995). A temperature of $60{ }^{\circ} \mathrm{C}$ and a pH of 3.5 , values which were optimal for RNase B1

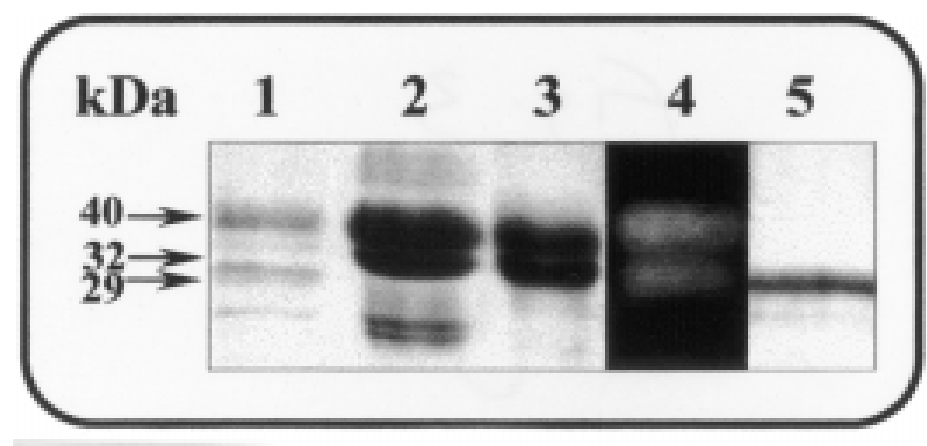

Fig. 3. SDS-PAGE zymogram of the RNase B1 purification steps. Lane $1=$ crude filtrate; lane $2=$ proteins eluted from the EMD-TMAE column at $0.62 \mathrm{M} \mathrm{NaCl}$; lane $3=$ proteins eluted from the Mono-Q column at $0.5 \mathrm{M} \mathrm{NaCl}$; lane $4=$ same as lane 3, except the proteins were assayed for RNase activity in situ and stained with toluidine blue; lane $5=$ purified RNase after deglycosylation by PNGase; lanes 1 to 3 and 5 were stained with coomassie blue. 


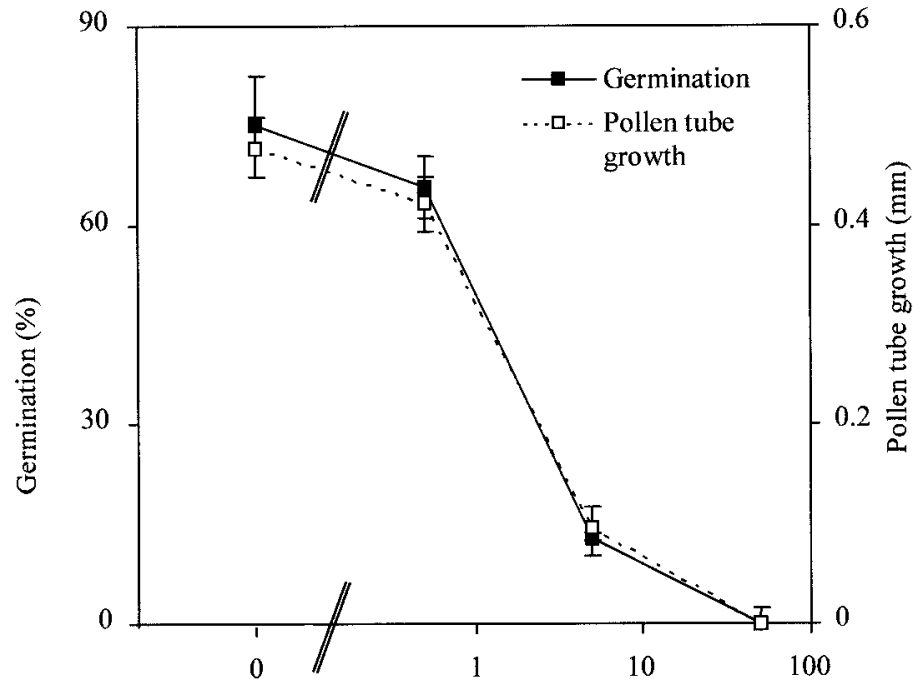

RNase concentration (units $/ \mathrm{mL}$ )

Fig. 4. Effect of different concentrations of A. niger B-1 RNase on peach pollen germination and pollen tube growth in vitro. For percentage germination, at least 100 pollen grains in each sample were monitored. For pollen tube growth, 10 pollen tubes in each sample were measured. Each point is the mean of three replications. Vertical bars $=\mathrm{SE}$.
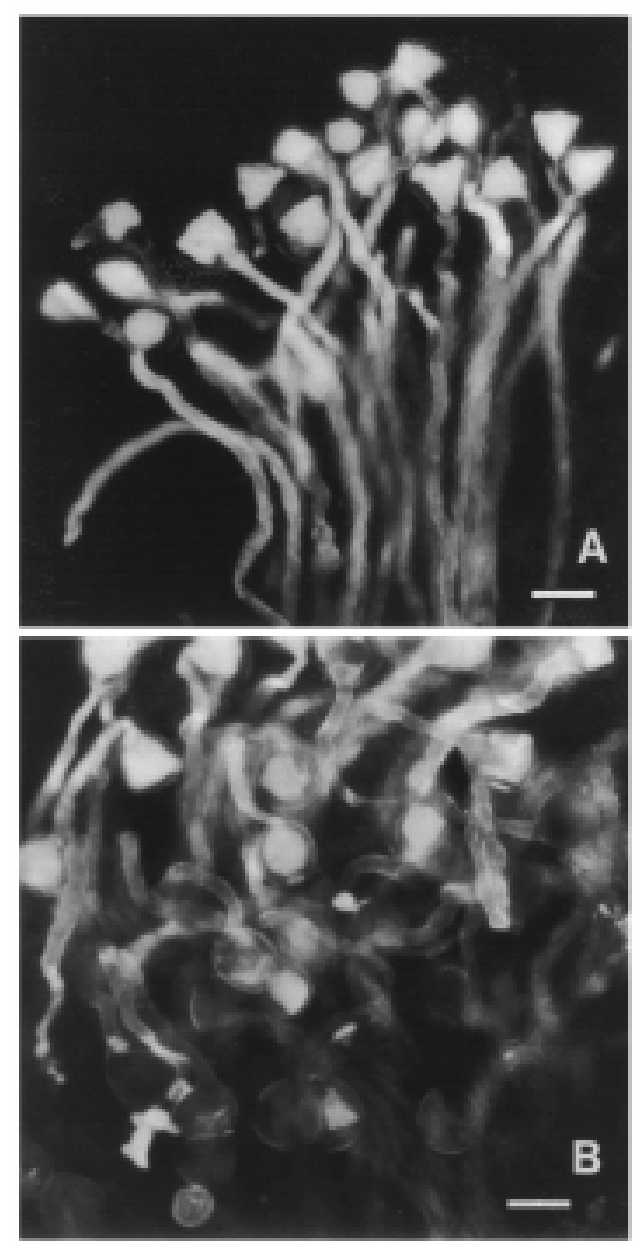

Fig. 5. Effect of RNase B1 on peach pollen tube growth in the stigma and the upper part of the style. (A) Control flower that was exposed to open pollination for 48 h. (B) Flower that was treated with RNase B1 before pollination. Scale bars = $0.2 \mathrm{~mm}$. activity, are also optimal for the activity of $\beta$-glucosidase produced by this strain (Shoseyov et al., 1988). In related species, extracellular RNases have been found to require similar conditions for optimal activity. For example, Horitzu et al. (1974) reported on A. niger NCR-A-1-233 RNase $\left(50{ }^{\circ} \mathrm{C}, \mathrm{pH} 3.5\right)$ and RNase $\mathrm{T}_{2}(\mathrm{pH} 4.5)$ and Irie (1967) reported on A. saitoi $\mathrm{RNase} \mathrm{M}$ $\left(50{ }^{\circ} \mathrm{C}, \mathrm{pH} 4\right)$ and Rhizopus niveus $\mathrm{RNase} \mathrm{Rh}\left(50^{\circ} \mathrm{C}, \mathrm{pH} 5\right)$. All these RNases have molecular weights between 24 and $34 \mathrm{kDa}$. They are also base-nonspecific enzymes with a preference to adenilic acid (Ohgi et al., 1991; Watanabe et al, 1990).

Secretion of considerable amounts of RNase should have a substantial biological role. In microorganisms, extracellular RNases are accepted generally to contribute to digestion of polyribonucleotides present in the growth medium, thereby giving rise to diffusible nutrients (Egami and Nakamura, 1969). These so-called nutritive characteristics of RNases have also been described in plants: cells of tomato (Lycopersicon esculentum Mill.) suspension cultures secreted RNase into the growth medium in response to phosphate starvation (Nurnberger et al., 1990). Nevertheless, more research is needed for a complete understanding of the physiological role of fungal extracellular RNases.

RNase $B_{1}$ was purified to homogeneity. PNGase deglycosylation, followed by appearance of a single 29-kDa band, indi-
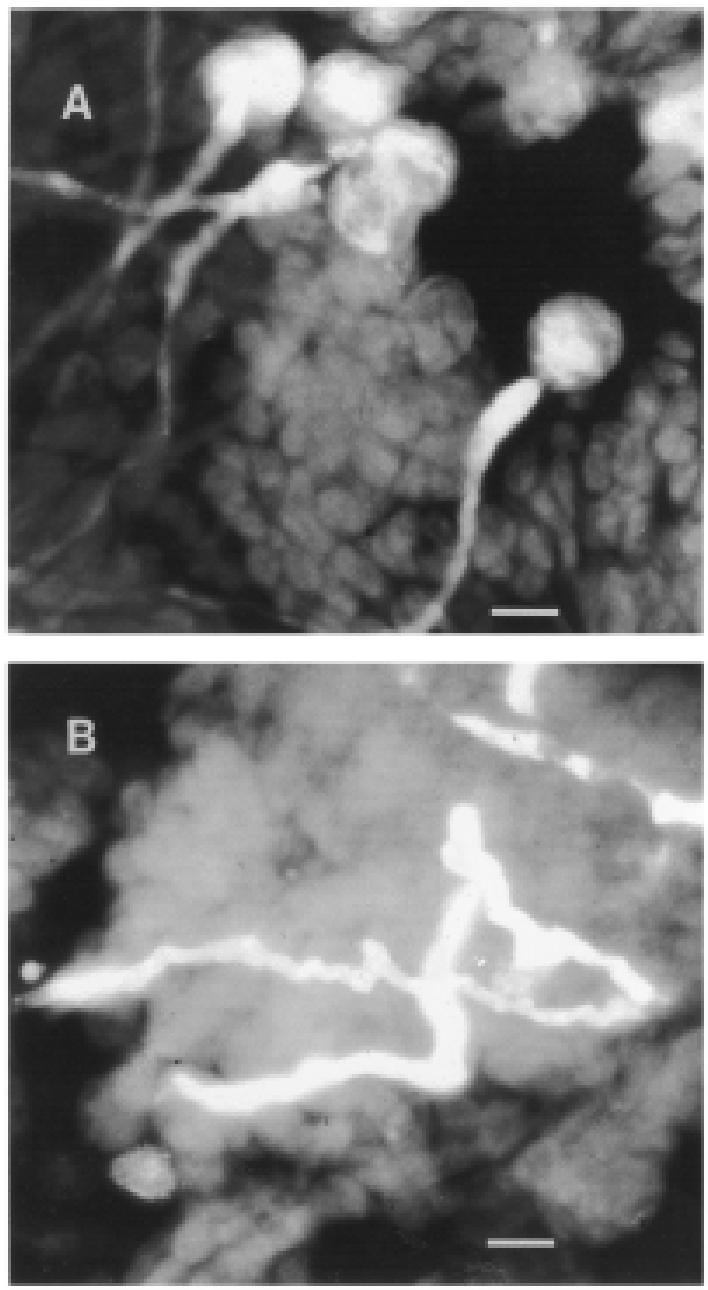

Fig. 6. Effect of RNase B1 on tangerine pollen tube growth in the stigma. (A) Control flower that was exposed to open pollination for $48 \mathrm{~h}$. (B) Flower that was treated with RNase before pollination. Scale bars $=0.1 \mathrm{~mm}$. 
Table 2. Fruit set of 'Fantasia' nectarine in Rosh Zurim, Israel. The buffer was sodium citrate, $\mathrm{pH} 3.5$, containing $0.025 \%$ triton X-100. Fruit set is expressed as the percentage of developed fruit per flower.

\begin{tabular}{lcc}
\hline \hline Treatment & $\begin{array}{c}\text { Flowers } \\
\text { (total no.) }\end{array}$ & $\begin{array}{c}\text { Fruit set } \\
(\%)\end{array}$ \\
\hline Control nontreated & $169^{\mathrm{z}}$ & $48.3 \mathrm{a}^{\mathrm{y}}$ \\
Control buffer & 143 & $36.3 \mathrm{~b}$ \\
500 units/mL RNase B1 & 148 & $23.3 \mathrm{bc}$ \\
1000 units/mL RNase B1 & 106 & $18.4 \mathrm{c}$ \\
\hline
\end{tabular}

${ }^{\mathrm{z}}$ Each value is the mean of 10 replications.

${ }^{y}$ Mean separation by Tukey-Krammer multiple range test, $P \leq 0.05$.

cates heteroglycosylation of this protein. RNase $\mathrm{T}_{2}$ (Kanaya and Uchida, 1981) and RNase M (Ohgi et al., 1983; Watanabe 1990) have also been found to contain different isoforms, sharing the same protein moiety, but differing in carbohydrate content. In RNase $\mathrm{T}_{2}$ the occurrence of different-size glycan chains has been suggested to be due to enzymatic degradation by glycosidases, which are also present in A. oryzae medium-filtrate (Kanaya and Uchida, 1981. In $P$. inflata, $\mathrm{S}_{3}$ protein, which normally has a single glycan chain, was mutagenized and gave rise to $\mathrm{S}_{3}(\mathrm{~N} 29 \mathrm{D})$, a nonglycosylated protein. The ability of $\mathrm{S}_{3}(\mathrm{~N} 29 \mathrm{D})$ protein to gain complete inhibition of $\mathrm{S}_{3}$ pollen indicates that the carbohydrate moiety is not necessarily required for the self-incompatibility reaction (Karunanandaa et al.,1994). In Lycopercion peruvianum (L.) Mill. the $\mathrm{S}_{3}$-RNase has a single $\mathrm{N}$-glycosylation site to which one of three n-glycans is attached (Parry et al., 1998). The exact biological role of the glycans is not understood. The molecular model of Parry et. al. (1998) suggest that the glycans are not involved in determining the self-incompatibility phenotype. It is possible the glycans play a role in the maintenance of glycoprotein stability and in improving their solubility (Rademacher et al., 1988, Parry et al., 1998).

In the present work, RNase B1 had a clear inhibitory effect on pollen germination and tube growth, in vitro as well as in vivo. The optimal temperature for RNase B 1 activity is $60^{\circ} \mathrm{C}$, however, at $25{ }^{\circ} \mathrm{C}$ the enzyme still possesses $25 \%$ of it's activity. In both peach and tangerine the appearance of the RNase-treated pollen tubes resembled the morphological features described in incompatible pollen tubes for Petunia hybrida Hort. Vilm.-Andr. (Herrero and Dickinson, 1980) and Papaver rhoeas L. (FranklinTong and Franklin, 1992). The pollen tubes were short, burst easily, had irregularities in wall deposition, and lacked a definite growth orientation. In gametophytic self-incompatible plants, the S-RNases have been found to share homology with RNase T2, RNase Rh, and RNase M (Haring et al, 1990; McClure et al., 1989). In previous work we described intensive callose deposition in RNase-inhibited pollen tubes in calamondin in response to stigmatic RNase and RNase T1 (Roiz et al., 1995). The inhibitory effect of RNase B1 on pollen tube growth appears to resemble that of the other RNases.

In nectarine, RNase B1 treatment reduces fruit set, indicating that its ability to inhibit pollen tube growth in the style may lead to a decrease in the fertilization rate. During the first month following blooming period, fruitlets born on RNase-treated branches were smaller and showed larger falling ratio than the controls. The fact that RNase B1 affected the embryos viability, may indicate its potential to interfere with fertilization.

In conclusion, $A$. niger $\mathrm{B} 1$ was found to be an efficient source of RNase. The RNase B1 inhibited pollen germination and pollen tube growth nonspecifically, but pollen tubes of treated pollen displayed morphological traits similar to those in gametophytic self-incompatibility. Much work is still needed to formulate RNase B1 as an effective control agent. However, based on this work the potential of its biological effect is clear, with its additional advantage of being environmentally safe.

\section{Literature Cited}

Bradford, M.M. 1976. A rapid sensitive method for the quantification of microgram quantities of protein utilizing the principle of protein-dye binding. Anal. Biochem. 72:248-245.

Broothaerts, W., P. Vanvinckenroye, B. Decock, J. Van Damme, and J.C. Vendrig 1991. Petunia hybrida S-proteins: Ribonuclease activity and the role of their glycan side chains in self-incompatibility. Sexual Plant Reprod. 4:258-266.

Brown, P.H. and T.-H.D. Ho. 1986. Barley aleurone layers secrete a nuclease in response to gibberellic acid. Plant Physiol. 82:801-806.

Clarke, A.E. and E. Newbigin. 1993. Molecular aspects of self-incompatibility in flowering plants. Annu. Rev. Genet. 27:257-279.

Clarke, K.R., J.J. Okuley, P.D. Collins, and T.L. Sims. 1990. Sequence variability and developmental expression of S-alleles in self-incompatible and pseudo self-incompatible Petunia. Plant Cell 2:815-826.

de Nettancourt, D. 1977. Incompatibility in Angiosperms, p. 28-57. In: R. Frankel, G.A.E. Gall, M. Grossmanand, and H.F. Linskens (eds.). Monographs on theoretical and applied genetics. vol. 3. SpringerVerlag, Berlin.

Egami, F. and K. Nakamura. 1969. Microbial ribonucleases. SpringerVerlag, Berlin.

Franklin-Tong, V.E. and F.C. Franklin. 1992. Gametophytic self-incompatibility in Papaver rhoeas L. Sexual Plant Reprod. 5:1-7.

Haring, V., J.E. Gray, B.A. McClure, M.A. Anderson, and A.E. Clarke. 1990. Self-incompatibility: A self-recognition system in plants. Science 250:937-941.

Herrero, M. and H.G. Dickinson. 1980. Pollen tube growth following compatible and incompatible intraspecific pollinations in Petunia hybrida. Planta 148:217-221.

Hinata, K., M. Watanabe, K. Toryama, and A. Isogai. 1993. A review of recent studies on homomorphic self-incompatibility. Intl. Rev. Cytol. 143:257-296.

Horitzu, H., Y. Higashi, and M. Tomoyedo. 1974. Production, purification and properties of ribonucleases from Aspergillus niger. Agr. Biol. Chem. 38:933-940.

Irie, M. 1967. Isolation and properties of a ribonuclease from Aspergillus saitoi. J. Biochem. 62:509-518.

Kanaya, S. and T. Uchida. 1981. An affinity adsorbent, 5'-adenylate aminohexyl—Sepharose. II. Purification and characterization of multiforms of RNase $T_{2}$. J. Biochem. 90:473-481.

Karunanandaa, B., S. Huang, and T-h. Kao. 1994. Carbohydrate moiety of the Petunia inflata $\mathrm{S} 3$ protein is not required for self-incompatibility interactions between pollen and pistil. Plant Cell 6:1933-1940.

Kaufmann, H., F. Salamini, and R.D. Thompson. 1991. Sequence variability and gene structure at the self-incompatibility locus of Solanum tuberosum. Mol. Gen. Genet. 226:457-466.

Kerns, G., O.N. Okunev, V.M. Ananin, and E.L. Golovlev. 1987. Enhanced formation of $\beta$-glucosidase by Aspergillus niger VKMF2092 in fed batch operation with frequency intermittent glucose addition. Acta Biotechnol. 7:535-545.

Kirch, H.H., H. Uhrig, F. Lottspeich, F. Salamini, and R.D. Thompson. 1989. Characterization of proteins associated with self-incompatibility in Solanum tuberosum. Theor. Appl. Genet. 78:581-588.

Laemmeli, U.K. 1970. Cleavage of structural proteins during the assembly of the head of bacteriophage T4. Nature 227:680-685.

Lee, H-S, A. Singh, and T-h. Kao. 1992. RNase X2, a pistil-specific ribonuclease from Petunia inflata, shares sequence similarity with solanaceous S proteins. Plant Mol. Biol. 20:1131-1141.

Li, L.H. and K.W. King. 1963. Fractionation of $\beta$-glucosidase and related extracellular enzymes from Aspergillus niger. Appl. Microbiol. 11:320-325. 
McClure, B.A., V. Haring, P.R. Ebert, M.A. Anderson, R.J. Simpson, F. Sakyiama, and A.E. Clarke. 1989. Style self-incompatibility gene products of Nicotiana alata are ribonucleases. Nature 342:955-957.

Newbigin, E., M.A. Anderson, and A.E. Clarke. 1994. Gametophytic self-incompatibility in Nicotiana alata, p. 5-18. In: E.G. Williams, A.E. Clarke, and R.B. Knox (eds.). Genetic control of self-incompatibility and reproductive development in flowering plants. Kluwer Academic Publishers, Dordrecht, Germany.

Nurnberger, T., S. Abel, W. Jost, and K. Glund 1990. Induction of extracellular ribonucleases in cultured tomato cells upon phosphate starvation. Plant Physiol. 92:970-976.

Ohgi, K., H. Horiuchi, H. Watanabe, M. Takagi, K. Yano, and M. Irie. 1991. Expression of RNase Rh from Rhizopus niveus in yeast and characterization of the secreted proteins. J. Biochem. 109:776-785.

Ohgi, K., H. Watanabe, M. Takizawa, Y. Kimura, K. Matsutani, E. Kakinuma, and M. Irie. 1983. Characterization of two forms of base non-specific and adenylic acid preferential ribonucleases from $\mathrm{As}$ pergillus saitoi. J. Biochem. 94:767-775.

Ozeri, U. 1995. Biological thinning of deciduous fruits and decreasing seed number in citrus fruits using fungal RNase. MS thesis, Hebrew Univ. Jerusalem.

Parry, S., E. Newbigin, D. Craik, K.T. Nakamura, A. Bacic, and D Oxley. 1998. Structural analysis and molecular model of a self-incompatibil- ity RNase from wild tomato. Plant Physiol. 116:463-469.

Rademacher, T.W., R.B. Parekh, and R.A. Dwek. 1988. Glycobiology. Annu. Rev. Biochem. 57:785-838.

Roiz, L., R. Goren, and O. Shoseyov. 1995. Stigmatic RNase in calamondin (Citrus reticulata var. Austera X Fortunella sp.). Physiol. Plant. 94:585-590.

Roiz, L. and O. Shoseyov. 1995. Stigmatic RNase in self-compatible peach (Prunus persica). Intl. J. Plant Sci. 156:37-41.

Rombout, F.M. and W. Pilnik. 1978. Enzymes in fruit and vegetable juice technology. Process Biochem. 89-13.

Sassa, H., H. Hirano, and H. Ikehashi. 1992. Self-incompatibility-related RNases in styles of Japanese pear (Pyrus serotina Rehd). Plant Cell Physiol. 33:811-814.

Shoseyov, O., B.A. Bravdo, R. Ikan, and I. Chet. 1988. Endo $\beta$ glucosidase from Aspergillus niger grown on a monoterpene glycoside-containing medium. Phytochemistry 27:1973-1976.

Singh, A. and T-H. Kao, 1992. Gametophytic self-incompatibility: Biochemical, molecular, genetic and evolutionary aspects. Intl. Rev. Cytol. 140:449-483.

Watanabe, H., A. Naitoh, Y. Suyama, N. Inokichi, H. Shimada, T. Koyama, K. Ohgi, and M. Irih. 1990. Primary structure of base nonspecific and adenylic acid preferential ribonuclease from Aspergillus saitoi. J. Biochem. 108:303-310. 